\title{
DIMENSI TEMA CERPEN "PENGARANG TELAH MATI" KARYA SAPARDI DJOKO DAMONO: PENDEKATAN PRAGMATIK
}

\author{
Erisy Syawiril Ammah ${ }^{1}$ Sudarsri Lestari ${ }^{2}$ \\ IAIN Jember, IAI Ibrahimy Banyuwangi \\ Email: ${ }^{1}$ syawirilammah@gmail.com, ${ }^{2}$ lilis@ibrahimy.ac.id
}

\begin{abstract}
The process of analysis used in this short story is to reveal the theme carried Sapardi Djoko Damomo in his work entitled "Pengarang Telah Mati" through pragmatic approach. This is because the theme is not within the realm of explicit that can be known directly by the reader, but the theme of short story "Pengarang Telah Mati" are in semantic areas described in each problematic in the story. Authors who have discretion in creating an autonomous world of authorship will be trying to hide something that will be delivering a message from a short story. This will provide the knowledge, experience, entertainment and benefit to the reader. Based on data analysts that have been done with a pragmatic approach, it can be concluded that theme "Pengarang Telah Mati" about accountability. A firmness to someone to be responsible for the actions he has dared to do and not leave him.
\end{abstract}

Keywords: Theme Short Story, Pengarang Telah Mati, Pragmatic Approach.

\section{Pendahuluan \\ Latar Belakang}

Cerita pendek (cerpen) sebagai karya sastra seperti juga karya sastra yang lainya, membentuk dunia rekaan [baca imajinasi] berdasarkan realitas kehidupan dan fenomena sosial yang ada. Cerita pendek cenderung padat dan langsung pada tujuannya dibandingkan karya-karya fiksi yang lebih panjang, seperti novella (dalam pengertian modern) dan novel. Karena singkat dan padatnya, cerita pendek sukses mengandalkan teknik-teknik sastra seperti tokoh, plot, tema, bahasa dan insight secara lebih luas dibandingkan dengan fiksi yang lebih panjang. Hal ini mengakibatkan tema yang diusung oleh pengarang dalam sebuah cerpen berada dalam wilayah semantis yang tersirat, yang direpresentasikan melalui problematis yang dikemas di dalam cerpen. Tema tersebut benarbenar hidup tercermin dalam komponen cerita di dalamnya.

Tema yang terdapat dalam sebuah karya sastra (cerpen, roman, novel) biasanya terletak pada ranah tersirat masalah yang di bicarakan. Tema merupakan unsur penting yang harus ada dalam sebuah cerita pendek baik secara implisit maupun eksplisit, karena temalah yang menjadi dasar sebuah cerita. Hal ini sesuai dengan yang diungkapkan tarigan (1985:125):

1) Setiap fiksi harus mempunyai dasar atau tema yang mempunyai sasran atau tujuan;

2) Tema adalah dasar atau makna sebuah cerita;
3) Tema adalah pandangan hidup yang tertentu atau perasaan tertentu yang membentuk atau membangun dasar gagasan-gagasan utama dari suatu kaarya sastra.

Dalam sebuah cerita rekaan, tema berfungsi memberi kontribusi (sumbangan) bagi elemen cerita rekaan yang lain seperti alur, tokoh, dan latar. Pengarang menyusun alur, menciptakan tokoh, dan yang berlakuan dalam latar tertentu, sebenarnya merupakan tanggapannya terhadap tema yang telah dipilih dan yang akan selalu mengarahkannya (Rahmanto dan Hariyanto, 1998:2.20).

Dalam hal ini terkadang seorang pembaca akan kesulitan menemukan sebuah tema yang terkandung dalam suatu hasil proses kreatif yang berbentuk cerpen, apabila pembaca tidak dapat masuk dalam dunia otomon kepengarang dan berdialog denganya. Masalah yang ditimbulkan dalam pengungkapan sebuah tema yang didasarkan pada titik fokus berbagai pembaca adalah pandangan subjektif dari setiap pembaca. Tapi dengan adanya pandangan yang berbeda-beda dari pembaca, hal ini tidak akan jauh keluar dari masalah yang ingin disampaikan oleh seorang pengarang, karena ini dipengaruhi oleh faktor resepsi setiap pembaca.

Berbagai kendala yang telah disebutkan diatas terbukti dalam salah satu cerpen karangan Sapardi Djoko Damono yang berjudul "Pengarang Telah Mati". Di sini pembaca merasa kesulitan dalam mengungkapakan tema apa yang diusung dalam cerpen tersebut. akhirnya 
banyaklah resepsi tema yang dikemukakan oleh pembaca secara subjektifitas. Cerpen yang mengisahkan seorang tokoh cerita fiksi yang menuntut pengarang agar untuk menyelesaikan ceritanya, karena sudah ditinggal mati oleh pengarang sebelum selesai ceritanya. Tapi kelihaian seorang Sapardi Djoko Damono dengan meyembunyikan hubungan semantik judul cerpen denga setiap representasi penceritaan setiap tokohnya, menjadikan timbul berbagai pertanyaan dalam diri pembaca, sebenarnya apa yang ingin disampaikan oleh seorang Sapardi Djoko Damono dalam cerpennya ini.

\section{Sekilas Cerpen Pengarang Telah Mati}

Cerpen "Pengarang Telah Mati" adalah salah satu karya Sapardi Djoko Damono. Pengarang yang lahir di Solo, Jawa Tengah karya-karyanya sudah tidak asing lagi bagi kalangan pembaca karya sastra. Cerpen ini terdiri dari delapan belas bab, empat belas bab isi dan empat bab sampiran. Yang membuat menarik dalam cerpen ini adalah menyuguhkan sebuah dunia otonom yang benar-benar atas kekuasaan seorang pengarang. Cerpen "Pengarang Telah Mati" banyak mengungkapkan problematika kehidupan yang digambarkan melalui tokohtokohnya, dan direpresentasikan melalui gaya penulisan yang indah dan semi puitis. Bahkan, dalam cerpen ini mengandung kritik sosial dan memuat pandangan hidup berisikan nilai-nilai kemanusiaan yang dapat memberikan pengetahuan dan pengalaman pada pembaca. Horace menyatakan bahwa hakekat seni adalah dulce et utile atau seni itu indah dan berguna (Wellek dan Warren, 1995:25). Jadi, karya sastra selain bersifat menghibur juga bermanfaat bagi penikmatnya.

Cerpen "Pengarah Telah Mati" mengisahkan seorang tokoh dalam cerita yang ditinggal mati oleh pengarang [penulis] sebelum cerita tersebut selesai. Tokoh utama itu bernama Sukram, seorang sarjana pulang dari belajar lanjutan di sebuah Universitas di Amerika. Di sana Sukram bertemu Ida, perempuan muda, anak seorang usahawan yang belajar atas biasa sendiri. Sukram mempunyai istri yang namanya minuk dan Esa anaknya. Ada juga Rosa, mahasiswa yang selalu aktif dalam kegiatan kampus. Yatno, rekan pengajar Sukram yang telat kawin yang pernah dekat dengan Minuk waktu kuliah. Bonar, kakak kelas Minuk di SMA dan menjadi pengusaha, baru cerai dari istrinya. Sekali-sekali suka menelepon Minuk, terutama ketika suaminya di luar negeri.
Latar cerita cerpen ini adalah huru-hara di Jakarta bulan Mei tahun 1998 di mana saat ini Indonesia sedang panas menuntut adanya reformasi. Hubungan antara Sukram dan Ida, Sukram dan Rosa, Sukram dan istrinya tentu saja dan antara Minuk, Bonar, dan Yatno sesudah peristiwa kunci itu.

\section{Pembahasan \\ Analisis Tema Cerpen "Pengarang Telah Mati"}

Setelah menggauli cerpen "Pengarang Telah Mati" karya Sapardi Djoko Damono, ternyata tema berada dalam wilayah semantis yang tersirat dalam berbagai konteks struktural, yang membutuhkan pemahaman secara mendalam dan sungguh terhadap segala sesuatu yang dipaparkan dalam cerita. Untuk mencari tema dalam cerpen ini digunakan sudut pandang pragmatik, yang memberikan perhatian utama terhadap pembaca.

Pendekatan pragmatik menurut Abram (1958:14-21) memberikan perhatian utama terhadap peranan pembaca. Pendekatan ini memberikan perhatian pada pergeseran dan fungsi-fungsi baru pembaca. Pendekatan pragmatik mempertimbangkan implikasi pembaca melalui berbagai kompetensinya. Setelah diadakan responsi pembaca terhadap cerpen Pengarang Telah Mati, ternyata diketahui berbagai pandangan yang dikemukakan oleh pembaca mengenai tema cerpen tersebut. Berikut ini adalah pandangan dari pembaca.

Pertama, pembaca berpendapat bahwa tema yang diangkat dalam cerpen telah mati adalah masalah perselingkuhan tokoh utama Sukram. Hal ini dapat didasarkan pada data yang mengenai perselingkuhan dalam cerpen tersebut.

File 1 hal. 48

Data: alenia 1

"lho, kok nelepon?"Suara ida.

"Apa nggak boleh?"

"Bukan, maksudku pesawatnya apa belum berangkat? ini kan sudah pukul sebelas, aku bayangkan sudah di atas lautan." ....

Berdasarkan data tersebut dapat diketahui bahwa tokoh utama, Sukram ada hubungan khusus dengan Ida, hal ini karena di waktu yang sangat genting, diceritakan bahwa kapal yang dinaiki Sukram ada kerusakan mesin dan malah menelpon Ida dan tidak menelpon istrinya sendiri. Hubungan khusus yang 
dilakukan oleh Sukram juga diperkuat pada data berikut.

File 15 hal. 110

Data: alenila 1

Aku sudah menerima e-mailmu yang ringkas itu, ida. Aku tidak bisa. Engkau adalah oasisku. Istri dan anakku. Aku tentu saja berjanji untuk tetap menunjjukkan telunjukku, kalau nanti kita ketemu sehabis masa studimu....

Data tersebut menguatkan hubungan khusus yang dilakukan tokoh utama, Sukram dengan Ida, sukram tidak bisa bersama Ida dan juga tidak bisa meninggalkanya, Ida mengirimkan sebuah E-mail kepada sukram untuk hidup bersamanya, tetapi Sukram tidak dapat melakukan hal itu karena dia telah memiliki istri dan anak.

Kedua, pembaca berpendapat bahwa tema yang diusung dalam cerpen "Pengarang Telah Mati" adalah masalah politik, masalah reformasi kekuasaan yang akan dipaksakan oleh mahasiswa, hal ini didasarkan pada data sebagai berikut.

File 7 hal. 72

Data: alenia 2

....................Mereka itulah yang mengatakan bahwa sekarang ada tiga kekuatan besar yang sedang berhadaphadapan. Pemerintah yang korup, Mahasiswa yang militant, dan opurtunitis politik, mahsiswa harus tidak bergeser pada tujuan semula yaitu menumbangkan tatanan yang sudah direkayasa selama tiga puluh tahun ....

Melihat data tersebut diketahui bahwa ada konflik yang terjadi dalam ranah kekuasaan, adanya golongan mahasiswa yang mencoba untuk mengadakan reformasi kekuasaan pemerintah yang telah berkuasa selama tiga puluh tahun, yang dinilai banyak menimbulkan permasalahan seperti korupsi, kkn, manipulasi dll.

Beragamnya presepsi pembaca dalam menyimpulkan tema cerpen "Pengarang Telah Mati" dikarenakan adanya simpulan awal yang dilakukan pembaca terhadap tema cerpen, yang seharusnya melakukan penggaulan secara lebih mendalam. Presepsi dari pembaca akan dijadikan acuan pendukung untuk menganalisis secara lebih mendalam tema cerpen "Pengarang Telah Mati". Berikut ini adalah data yang berisi masalah yang paling penting dan menonjol yang dapat digunakan untuk menyimpulkan tema.
Menurut Esten (1984:92) ada tiga kriteria dalam menentukan tema mayor, yaitu:

1) Melihat persoalan yang paling menonjol.

2) Melihat persoalan yang paling banyak menimbulkan konflik, dan

3) Melihat persoalan yang paling banyak membutuhkan waktu penceritaan.

Apabila melihat pada bagian TAMU maka akan ditemukan problematis yang diangkat pada cerpen Pengarang Telah Mati, yang di sini akan menyimpulkan sebuah konstituen tema. Konstituen tema adalah label yang diberikan untuk mewadahi komponen sebuah penyusunan tema khusus (minor). Konstituen tema yang kemudian nanti digunakan untuk mengkonstruksikan suatu tema umum (mayor) dalam cerpen. Masalah tersebut terjadi pada pengarang yang telah mati, menjadikan tokoh utama protes dan meminta pertanggung jawaban pengarang.

\section{Data:}

Saudara, saya adalah salah seorang tokoh sebuah cerita yang ditulis seorang pengarang minggu lalu, meninggalkan ceritanya belum selesai. Maksud saya, sebelum sempat menyelsaikan ceritanya ia meninggal dunia. Saudara juga sempat melihat jenazahnya, bukan?wajahnya tentram sekali, seolah ia tidak punya masalah meninggalkan dunia ini. Padahal ia masih punya masalah besar, yakni menyelesaikan ceritanya. (hal 43)

Pernyataan di atas menjelaskan bahwa seorang tokoh yang menuntut seorang pengarang yang masih meninggalkan masalah di dunia, dengan belum menyelesaikan sebuah cerita yang pernah ditulisnya. Akibat dari penulisan cerita yang belum selesai oleh pengarang menimbulkan kekhawatiran tokoh-tokoh dalam cerita akan nasib mereka dalam cerita.

Data:

... Sesudah saya dan beberapa tokoh dilahirkan, rekan-rekan saya dalam cerita yang masih dalam proses penciptaan itu menghubungi saya, mereka tampak khawatir. Pengarang itu sudah payah sekali kesehatanya, kalau tiba-tiba ia mati, dan cerita tentang kita belum selesai, bagaiman nasib kita terutam nasibmu, yang menjadi tokoh utama? ....(alenia 2) 
Pernyataan di atas menjelaskan bahwa tokoh-tokoh yang diciptakan pengarang dalam ceritanya mulai panik dengan keadaan pengarang yang memburuk kesehatanya. Tokoh tersebut khawatir jika pengarang tidak dapat menyelesaikan ceritanya, menjadikan nasib mereka terkatung-katung tidak jelas. Ini diperkuat dengan data selanjutnya, tokoh utama Sukram belum tahu wataknya, yang masih ada dalam beberapa file.

Data:

Saya hanya ada dalam beberapa file di komputernya. Begitu berbagai-bagainya sehingga saya benar-benar tidak tahu watak saya apa. Ia seenaknya memberi nama saya sukram ...(alenia 3 )

Kutipan di atas menjelaskan bahwa tokoh utama (Sukram) belum mengetahui karakternya dalam ceritanya. Hanya terdapat beberapa file cerita dalam komputer pengarang untuk merepresentasikan watak tokoh sukram, yang tentunya itu belum cukup sama sekali. Akhirnya proses penciptaan cerita yang belum selesai akan berakibat pada jalan hidup tokoh-tokoh yang belum jelas.

Data:

Kami tidak bisa ditinggalkanya begitu saja. Proses penciptaan yang tidak selesai akan besar sekali akibatnya bagi yang diciptakan, bagi kami dan jalan hidup kami ...(alenia 5)

Pernyataan yang dikemukakan tokoh tersebut menggambarkan bahwa banyak sekali akibat yang ditimbulkan dari proses penciptaan yang belum selesai. Terutama pada jalan hidup tokoh yang ada dalam cerita.

Konstituen tema dari data bagian TAMU adalah jika seseorang sudah terlanjur memulai suatu pekerjaan (cita-cita) harus bisa juga menyelesaikanya sampai akhir (menggapainya).

Apabila melihat pada bagian AKU terdapat masalah penting yang dapat ditemukan, masalah tersebut adalah Sukram sebagai seorang tokoh utama, terlanjur diciptakan oleh pengarang, yang berhak tahu jalan kehidupan meskipun hanya hanya dalam sebuah cerita.

Data:

.... aku tidak boleh apa-apa saja padanya. Ia sudah terlanjur diciptakan, seperti katanya sendiri waktu itu kami pertama kali bertemu, dan dia akan menetap diantara huruf-huruf yang telah ditulis sahabatku itu'.... tetapi seperti juga manusia, ia tentu memiliki rasa ingin tahu apa yang terjadi dengan kehidupanya. Meskipun rekaan. (hal 99)

Pernyataan di atas menjelaskan bahwa aku (sudut pandang orang ketiga mahatahu) tidak boleh membiarkan tokoh-tokoh dalam cerita hanya diam begitu saja. Maksudnya di sini adalah harus mencari file-file dalam komputer pengarang untuk di susun menjadi sebuah cerita yang padu. Ini dilakukan dengan kesadaran bahwa meskipun hanya sebuah tokoh dalam cerita tapi tokoh tersebut adalah tokoh yang hidup dalam dunia cerita pengarang, maka tetap wajib jika tokoh tersebut mengetahui jalan ceritanya sampai akhir.

Hal ini diperkuat dengan data selanjutnya tokoh Sukram mendesak AKU untuk menjadikan Ia tokoh fiksi yang mengerti dan benar-benar ada dalam cerita.

Data:

Rupanya Sukram tahu bahwa file-file itu tidak dibuka, ia belum menjadi tokohtokoh fiksi baru menjadi ada jika dibaca, jika sudah masuk ke benak manusia. Jika semиa yang ditulis sahabatku lenyap begitu saja, dan belum sempat dibaca, Sukram akan mengembara seperti roh yang gentayangan selamanya dialam ajaib....(alenia 1)

Pernyataan yang jelas dari tokoh utama bahwa jika file-file tersebut belum dibaca dan masuk ke dalam diri manusia, maka Ia belum dikatakan hidup dalam sebuah cerita. Apabila hal tersebut berkelanjutan sehingga file-file yang ada dalam komputer pengarang dibiarkan begitu saja, maka tokoh utama khawatir jika tiba-tiba file tersebut terkena virus. Jika demikan akan menjadikan tokoh-tokoh dalam cerita akan mengembara seperti roh gentayangan selamanya dialam ajaib kepengarangan.

Setelah melihat data bagian AKU, sehingga dapat disimpulkan bahwa konstituen temanya adalah bahwa suatu pekerjaan (cita-cita) yang tidak terselasaikan akan berdampak buruk dan serta menimbulkan kerugian bagi dirinya dan orang lain. Tindakan pengarang yang belum selesai menyelesaikan ceritanya menimbulkan problem terhadap tokohya, tokoh dalam cerita tersebut belum mengetahui jalan nasibnya, dan apabila file-file yang belum diselesaikan oleh pengarang terkena virus dan terhapus maka tokoh-tokoh dalam cerita akan gentanyangan dalam cerita (dramatisnya). 
Apabila melihat pada masalah penting FILE 15 dapat diketahui bahwa Sukram tidak dapat meninggalkan anak dan istrinya, tapi juga tidak dapat bersama Ida.

Data:

Aku sudah menerima e-mailmu yang ringkas itu, ida. Aku tidak bisa. Engkau adalah oasisku. Istri dan anakku. Aku tentu saja berjanji untuk tetap menunjjukkan telunjukku, kalau nanti kita ketemu sehabis masa studimu.... (hal 110)

Pernyataan di atas menceritakan bahwa tokoh utama dalam hal ini Sukram, telah menerima dan membaca e-mail dari Ida, yang isinya adalah surat cinta kepada Sukram. Ida meminta Sukram untuk menjadi pendamping hidupnya, tapi di sini Sukram tidak bisa karena telah memiliki istri dan anak. Sukram hanya menganggap Ida sebagai oasis yang menemani perjalanan hidupnya. Hal ini juga diperkuat dengan data selanjutnya

Data:

.... Oasis yang dengan sabar menunggu pengembara yang menempuh perjalanan, dan mungkin tersesat, di padang pasir. Pengembara selalu saja membayangkan oasis itu, meskipun sering kali, sayang sekali, menemukan oasis lain. (alenia 1)

Di sini Sukram tidak bersungguhsungguh kepada Ida karena dia hanya merupakan oasis (sumber kehidupan) masa lalunya. Kehidupan Sukram yang seperti pengembara di padang pasir yang menemukan kesejukan dan kesegaran dalam perjalananya.

Apabila melihat data File 15 tersebut, dapat disimpulkan konstituen tema bahwa seseorang harus mempunyai prinsip dalam menyelesaikan segala persolan yang terjadi dalam kehidupanya. Hal ini terlihat bahwa tokoh utama Sukram menjalin hubungan khusus dengan Ida dan dia tidak bisa mengkhiri hubungan tersebut sehingga timbul berbagi masalah dalam kehidupanya.

Setelah proses analisis dilakukan sehingga dapat ditemukan konstiuen-konstituen tema dalam setiap masalah yang penting dan paling menonjol, konstituen tema tersebut dikonstruksikan menjadi tema umum, sehingga diperoleh bahwa tema yang diusung dalam cerpen "Pengarang Telah Mati" berkaitan dengan pertanggungjawaban. Setiap perbuatan yang telah dilakukan pakan dipertanyakan tanggung jawabnya, maka apabila seseorang berani memulai sesuatu juga harus berani mengakhirinya.

\section{Simpulan}

Apabila menganalisis karya sastra dengan pendekatan pragmatik, akan timbul bermacam-macam presepsi oleh pembaca. Hal ini menandakan kompetensi pemerolehan yang berbeda antara pembaca yang satu dengan pembaca yang lain, memang sepertinya bersifat subjektif dalam mengapresiasi karya sastra, tetapi hasil apresiasi yang bersifat subjektif akan dikumpulkan menjadi satu untuk dilakukan analisis dan pengajian yang kemudian melahirkan sebuah apresiasi objektif.

Cerpen Pengarang Telah mati Karya Sapardi Djoko Damono, merupakan sebuah cerpen yang mengangkat tema pertanggung jawaban. Sebuah ketegasan kepada seseorang agar bertanggung jawab atas perbuatan yang ia telah berani lakukan dan tidak meninggalkannya. Hal ini digambarkan tokoh utama yang bernama Sukram. Berbagai masalah yang dialami tokoh Sukram, melukiskan tema yang diusung oleh pengarang. Dalam cerpen Pengarang Telah Mati perilaku tokoh mempunyai hubungan dengan judul, hal ini dapat dilihat pada setiap masalah penting yang dialaminya memunyai hubungan yang tersirat.

\section{Daftar Rujukan}

Abdullah, M. Yatimin. 2005. Pengantar Studi

Etika. Jakarta: PT Raja Grafindo Persada.

Aminuddin. 1987. Pengantar Apresiasi Sastra. Bandung: Sinar Baru.

Damono, Sapardi Djoko. Pengarang Telah Mati. Lubis, Mochtar. 1996. Sastra dan Tekniknya. Jakarta: Yayasan Obor Indonesia.

Nurgiyantoro, Burhan. 2000. Teori Pengkajian Fiksi. Yogyakarta: Gadjah Mada University Press.

Minderop, Albertine. 2005. Metode Karakterisasi Telaah Fiksi. Jakarta: Yayasan Obor Indonesia.

Wellek, Rene \& Austin Warren. 1993. Teori Kesusastraan. Diterjemahkan oleh Melani Budianta. Jakarta: Gramedia. 
Volume 4 No. 1 METALINGUA

April 2019 Jurnal Pendidikan Bahasa dan Sastra Indonesia 